\begin{tabular}{|c|c|c|c|}
\hline $\begin{array}{c}\text { RESEARCH } \\
\text { ARTICLE }\end{array}$ & $\begin{array}{r}\text { ADVANCE RESEARCH JOURNAL OF } \\
\text { volume } 6 \mid \text { Issue } 2 \mid \text { December, 2015 | 255-257 }\end{array}$ & $\begin{array}{l}\text { F SOCIAL SCIENCE } \\
\text { e ISSN-2231-6418 }\end{array}$ & \\
\hline $0=$ & DOI: 10.15740/HAS/ARJSS/6.2/255-257 & Visit us : www.researchjournal.co.in & \\
\hline
\end{tabular}

\title{
Evaluation of acceptability of nutritious ready-to-eat foods for the elderly
}

Prema B. Patil* and Sunanda K. Itagi

Krishi Vigyan Kendra (U.A.S.), VIJAYPUR (KARNATAKA) INDIA

(Email : dr_prema74@yahoo.com)

\section{ARTICLE INFO :}

$\begin{array}{lll}\text { Received } & : & 04.11 .2015 \\ \text { Revised } & : & 17.11 .2015 \\ \text { Accepted } & : & 24.11 .2015\end{array}$

KEY WORDS :

Elderly, Ready-to-eat, Foods, Acceptability, Nutritious, Recipes

HOW TO CITE THIS ARTICLE :

Patil, Prema B. and Itagi, Sunanda K. (2015). Evaluation of acceptability of nutritious ready-to-eat foods for the elderly. Adv. Res. J. Soc. Sci., 6 (2) : 255257.

\begin{abstract}
Aging generally changes the relationship with foods as well as what the bodies require from the foods we eat. Relatively little is known about how the nutritional needs of older people differ from those who are younger. With advancing age, the elderly are more likely to suffer from dental problems. Ill-fitting dentures, pain in jaws, mouth sores and missing teeth can make chewing painful. All of these factors create difficulty for the elderly to eat healthy foods. Further during old age, people tend to be disinterested in cooking food everyday and often not keen in opting for variety of foods. In some cases, food becomes monotonous and a few start skipping their meals resulting in malnutrition. But eating a well-planned diet and proper nutrition brings strength and vitality to the elderly. So there is a need for ready-to-eat foods in present day context. Hence a study was carried out on evaluation of ready-to-eat foods for elderly. Some of the ready-to-eat foods like sorghum flakes, wheat flakes, multigrain mix, ragi rawa, Nuchhu, ragi vermicelli and ragi flakes were distributed to 85 elderly respondents. Acceptability of the above mentioned foods was tested using hedonic score method. Results revealed that ragi flakes was liked the most (100\%) and ragi vermicelli was liked the least (48\%). Also evaluation of nutritious health drinks was also carried out by the elderly. Results revealed that ragi malt was liked by majority ( 96 $\%$ ) of the respondents followed by ragi ambli (95\%), sorghum semolina porridge (87\%), horsegram porridge (85\%) and sorghum flour porridge (78\%). Thus its important to have a balanced diet with proper amounts of nutrients, vitamins and minerals. Seniors should be particularly careful about their diets as they must deal with additional agerelated health concerns.
\end{abstract}

